\title{
Bokrecension: The Coddling of the American Mind: How Good Intentions and Bad Ideas Are Setting Up a Generation for Failure
}

\author{
Niclas Lindström \\ Umeå universitet \\ Greg Lukianoff \& Jonathan Haidt (20I8). The Coddling of the American Mind: How Good \\ Intentions and Bad Ideas Are Setting Up a Generation for Failure. New York: Penguin Press, \\ 338 sid.
}

Den I5 augusti 2019 rapporterar the Guardian att Laurie Sheck, författare och universitetslärare i kreativt skrivande vid New School i New York, anmälts av en student och blivit föremål för en utredning (Flood, 20I9). Anledningen ska ha varit att hon använt en text, av den svarte författaren och människorättsaktivisten James Baldwin, som innehöll språkbruk vissa studenter upplevde som rasistiskt. Sheck kallades till ett möte med universitetsledningen där hon bland annat ombads besvara frågor om litteraturen och uppgifterna i undervisningen där hon menat att studenterna "... should reasonably be expected to be able to discuss painful or offensive language". Händelsen är på intet sätt unik. I media tecknas allt oftare bilden av studenter som reagerar kraftigt på idéer som inte överensstämmer med deras egna i t ex kurslitteratur eller föreläsningar. I den svenska debatten kopplas fenomenet ibland till utbredningen av en så kallad kränkthetskultur där studenter kan uppleva ett tillrättaläggande eller ett underkänt resultat som förödmjukande. Samtidigt rapporteras att lärare upplever att de får tassa på tå för att studenterna inte ska känna sig upprörda av undervisningen, drar sig för att ingripa i konflikter av rädsla för att bli anmälda för kränkande behandling och saknar institutionsledningens stöd (se t ex Harrison, 2016 samt Skogstad och Zafar, 2019).

Marc D. Hauser, före detta professor i psykologi vid Harvard University, har konstaterat att en anledning till problemen inom utbildningsområdet är en bristande förståelse av vår moralpsykologi: "The dominant moral-reasoning view has generated failed policies in law, politics, business, and education. I believe that a primary reason for this situation is our ignorance about the nature of our moral instincts and about the ways they work and interface with an everchanging social landscape (Hauser, 2006, xx).” Det är i ett försök att hantera just sådana frågor som Greg Lukianoff, jurist och ordförande för Foundation for Individual Rights in Education (FIRE), och Jonathan Haidt, professor i etiskt ledarskap vid New York University (2018), författat The Coddling of the American Mind: How Good Intentions and Bad Ideas Are Setting Up a Generation for Failure. Boken består av fyra delar som i tur och ordning behandlar utbredningen av en så kallad säkerhetskultur i samhället, hur den påverkar möjligheterna att bedriva undervisning och forskning vid universitet, varför förändringarna skett i så hög takt, samt ger avslutningsvis råd om hur universitetslärare kan hantera den nya situationen. Även om författarna

*Författarkontakt: niclas.lindstrom@umu.se

Artiklar och reflektioner är kollegialt granskade. Övriga bidragstyper granskas av redaktionen. Se www.hogreutbildning.se ISSN 2000-7558

(C)2019 Niclas Lindström. This is an Open Access article distributed under the terms of the Creative Commons Attribution-NonCommercial 4.0 International License (https://creativecommons.org/licenses/by-nc/4.0/), allowing third parties to share their work (copy, distribute, transmit) and to adapt it, under the condition that the authors are given credit, that the work is not used for commercial purposes, and that in the event of reuse or distribution, the terms of this license are made clear.

Citation: Niclas Lindström (2019) «Bokrecension: The Coddling of the American Mind: How Good Intentions and Bad Ideas Are Setting Up a Generation for Failure», Högre utbildning, 9(2), 25-28. http://dx.doi.org/10.23865/hu.v9.1821 
utgår från amerikanska förhållanden menar de inledningsvis att innehållet åtminstone delvis bör vara möjligt att tillämpa på andra platser som delar den problematik som tecknas i boken.

I den inledande delen av boken vill författarna visa hur tre falska idéer fătt spridning i samhället och bidragit till framväxten av vad som skulle kunna kallas för en säkerhetskultur (eng saftyism). Den första idén handlar om att människor är ömtåliga och i behov av både fysisk och emotionell säkerhet. I utbildningssammanhang kan det innebära att lärare t ex utfärdar triggervarningar om kurslitteraturen har ett innehåll som kan väcka obehag hos vissa personer eller helt undviker att ta upp kontroversiella frågor i undervisningen för att på så sätt värna om studenternas säkerhet. Den andra idén handlar om att vi alltid bör lita till våra känslor. Ifall vi känner oss förorättade eller kränkta i något sammanhang har någon sannolikt behandlat oss på ett respektlöst sätt. Det är inte vilka intentioner andra har med sitt agerande som är avgörande för hur det bör tolkas utan om det bidrar till individens subjektiva upplevelse av att vara utsatt för marginalisering eller förtryck. Den tredje idén handlar om att livet är en kamp mellan goda människor som vill andra väl och onda människor som vill andra illa. Gruppen individen själv tillhör motiveras av värderingar som sanning, jämlikhet och rättvisa samtidigt som man upplever att andra individer som tillhör andra grupper motiveras av värderingar som osanning, orättvisa och förtryck.

Den som är bekant med Jonathan Haidts arbeten inom det moralpsykologiska fältet sedan tidigare kommer att känna igen sättet att argumentera på. Upplägget följer i hög utsträckning den modell som först presenterades i den banbrytande artikeln ”The Emotional Dog and Its Rational Tail" (200I) och sedan utvecklades ytterligare i den uppmärksammade boken The Righteous Mind: Why Good People Are Divided by Politics and Religion (20I2). Där försvarar författaren idén om att våra moraliska omdömen i regel är emotionella eller intuitiva reaktioner på vad som sker i vår omgivning, som sedan $\mathrm{i}$ efterhand kompletteras med rationella argument för att motivera varför bedömningen är riktig. På liknande sätt inleder Lukianoff och Haidt nästan varje kapitel av boken med ett exempel, som ofta bygger på ett verkligt fall, för att väcka läsarens sympatier. Därefter vädjar författarna till läsarens intellekt och argumenterar utförligt, ofta med stöd av psykologisk forskning, för vart och ett av sina ställningstaganden. En svaghet som Haidt (200I) tidigare identifierat med ett sådant tankemönster är just att den känslomässiga reaktionen i efterhand ges ett rationellt berättigande, utan att hänsyn tas till vad som talar mot den. I viss mån skulle det kunna anföras som kritik mot bokens upplägg som sådant.

Lukianoff och Haidt (20I8) konstaterar t ex att de flesta fall de lyfter fram utgår från vad som, i ett amerikanskt sammanhang, betraktas som ett vänsterperspektiv: "the stories in this book have mostly presented problems on campus that arise from a part of the political left. Sometimes the targets were on the right ... but more often the targets were themselves on the left. If we were to limit our analysis to events on campus, this would be most of the story (I26 f)." Om vi får tro författarna kommer studenter att påverkas av en övervägande vänsterorienterad universitetslärarkår och deras ideologiskt färgade undervisning vilket bidrar till en polarisering, inte enbart av campus utan även av samhället i stort. I det här fallet behöver läsaren endast konsultera en av Lukianoffs och Haidts återkommande källor, Chronicle of Higher Education, för att hitta referenser till undersökningar som visar hur vit makt-propagandan ökat med 77 \% vid amerikanska campus bara under 2017 (se t ex Zahneis, 20I8). Dessa resultat gör det svårt att följa författarnas argumentation om att endast vänsteranhängare ska betraktas vara skyldiga till den politiska polarisering som skett vid universiteten. 
Varför väljer då författarna en sådan argumentationslinje? Ett tänkbart svar återfinns i Haidts (20I2) tidigare studier där författaren liknat människans medfödda förmåga att reagera moraliskt på olika händelser i sin omgivning vid en tunga, med skilda typer av receptorer, som tillsammans kan ge upphov till en mångfald av olika smaksensationer. Han beskriver dessa receptorer i termer av motsatspar; omsorg/skada, rättvisa/fusk, lojalitet/förräderi, auktoritet/subversivitet, helighet/ degration (I44 ff). Resonemanget använder han sedan för att förklara t ex framgångarna för konservativa politiker som vädjar till en bredare palett av känslor än liberaler som i första hand tenderar att fokusera på omsorg och rättvisa—vilket även avspeglat sig i amerikanska valresultat under de senaste årtiondena (I80 ff). I dessa studier har Haidt (20I2) beskrivit hur forskningsresultaten fått honom som liberal att medvetet försöka arbeta med att bredda sin smakrepertoar beträffande moraliska emotioner (II8 ff, I92 ff). Ett sätt att förstå detta är att författaren medvetet valt att bli mer konservativ i sitt tankesätt. Kanske kan även Lukianoffs och Haidts bok ses i ljuset av detta.

I den avslutande delen av boken ger författarna råd, till exempelvis föräldrar och universitetslärare, om hur det är möjligt att hantera den här typen av problem. De tre första råden anknyter direkt till de idéer som inledningsvis ansågs ligga till grund för utbredningen av den så kallade säkerhetskulturen. För det första bör vuxna förbereda ungdomarna för vägen och inte förbereda vägen för ungdomarna. På samma sätt som vi behöver exponeras för smittämnen för att utveckla vårt immunförsvar behöver vi ta del av andras tankar och få våra egna övertygelser ifrågasatta för att kunna utvecklas och mogna som människor. För det andra kan inte din värsta fiende skada dig lika mycket som dina egna tankar. Det är därför viktigt att bli medveten om sina egna kognitiva distorsioner, lyssna till andras argument samt bemöta dem i ett öppet samtal. För det tredje går gränsen mellan gott och ont rakt genom varje människas hjärta. Av den anledningen bör vi göra vårt bästa för att försöka förstå våra medmänniskor och på så sätt försöka komma bort från ett polariserat tankesätt.

Trots de brister som lyfts fram i denna recension blir slutsatsen ändå att Lukianoff och Haidt gjort ett ambitiöst försök att blottlägga orsakerna till varför studenter reagerar oftare och kraftfullare på innehållet i undervisningen än tidigare samt att formulera råd om hur lärare kan agera för att komma till rätta med problemen för att på så sätt främja ett öppet och kritiskt debattklimat vid högskolor och universitet. Att dessa praktiska råd, till skillnad från mycket annat, baseras på lärdomar av de senaste decenniernas moralpsykologiska forskning är intressant av olika skäl. För det första bygger råden på omfattande internationella studier om hur människor i allmänhet tenderar att reagera och reflektera över moraliskt känsliga frågor vilket eventuellt kan bidra till att öka sannolikheten för att dessa kan överföras till andra sammanhang än där författarna är verksamma. För det andra kan boken åtminstone delvis svara mot utmaningen, som inledningsvis formulerades av Marc Hauser, att policyer inom utbildning ofta är dömda att misslyckas just på grund av bristande förståelse av samspelet mellan individens moraliska instinkter och hennes sociala omgivning. Om inte annat är boken ett intressant och välskrivet diskussionsunderlag för dem som intresserar sig för frågor som berör t ex yttrandefrihet och lika villkor vid högskolor och universitet.

REFERENSER

Flood, A. (2019). “White professor investigated for quoting James Baldwin's use of N-word." The Guardian. 15 augusti. Tillgänglig: https://www.theguardian.com/books/2019/aug/15/white-professor-investigatedquoting-james-baldwin-use-of-n-word-laurie-sheck

Haidt, J. (2001). “The emotional dog and its rational tail: A social intuitionist approach to moral judgment”. Psychological Review, 108(4), 814-834. doi:10.1037/0033-295X.108.4.814 


\section{Niclas Lindström}

Haidt, J. (2012). The Righteous Mind, Why Good People Are Divided by Politics and Religion. Penguin Books. ISBN978-0-141-03916-9

Harrison, D. (2016). "Högre utbildning ett haveri". Svenska Dagbladet. 26 januari.

Hauser, M. (2006). Moral Minds, the Nature of Right and Wrong. New York: Harper Perennial.

Skogstad, I., \& Zafar, H. (2019). ”Kränkthetskulturen i skolan urholkar lärarnas auktoritet”. Dagens Nyheter. 4 mars.

Zahneis, M. (2018). "White-Supremacist Propaganda on Campuses Rose 77\% Last Year". Chronicle of Higher Education. Tillgänglig: https://www.chronicle.com/article/White-Supremacist-Propaganda/243786 